\title{
THE EFFECT OF PACKAGING ON HOT-CARCASS-BONED BEEF AND PORK
}

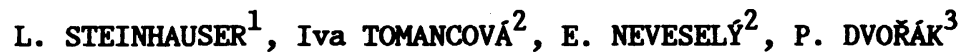

${ }^{1}$ Department of Food Hygiene and Technology, University

of Veterinary Science, 61242 Brno
${ }^{2}$ Centre for the Hygiene of Food Chains, Institute of Hygiene 3 and Epidemiology, 61242 Brno,

3 Municipal Hygienic Station Brno

Received June 5, 1987

\section{A b s $t$ r a c $t$}

$s$ t e $i$ n h a u s e r L., Iva T o m a n c o vá, E. N e $v$ e $s$ e $1 \dot{y}, \quad P$. $D v 0 \quad \check{r}$ á $k$ : The Effect of Packaging on Hot-Carcass-Boned Beef and Pork. Acta vet. Brno, 57, 1988: 61-71.

Compared were microbiological, chemical and sensory examinations of beef and pork( $m$. longissimus dorsi) boned while still hot and immediately packaged on dishes with shrinkable film, vacuum packaged and packaged in controlled atmospheres of $80 \% \mathrm{~N}_{2}$ and $20 \% \mathrm{CO}_{2}$ and of $80 \% \mathrm{O}_{2}$ and $20 \% \mathrm{CO}_{2}$.

Vacuum and controlled-atmosphere packaging markedly increased the storage life of meat and reduced the intensity of growth of the natural meat microflora. The best sensory results were observed in meat in the $\mathrm{O}_{2} / \mathrm{CO}_{2}$ atmosphere and no differences were found after heat treatment. Sensory deviations were found to be correlated with microbiological findings, some differences were found only when compared with ammonia values in controlled-atmosphere packaged meat. Weight losses of packaged pork were dependent, above all, on biochemical meat properties; however, also statistically significant were found differences amoung the individual types of packages after eliminating PSE defects. No differences were found in beef, similarly as in the other biochemical indicators of meat quality.

Meat packaging, vacuum packaging, controlled atmosphere.

The basic precondition for increasing the storage life of retail meat cuts observing the hygienic parameters of production, is meat packaging. In the past years, meat packaging, especially the progressive systems, have undergone great improvements all over the world.

In Czechoslovakia at the present time, about $15 \%$ of the total volume of market meat is packaged. By the end of 1995 this amount will have risen to $40 \%$. Out of this amount of packaged meat, the proportion of specially dressed meat will be $40 \%$.

In close connection with the systems of packaging, also the specific boning of meat, very frequently hot carcass boning, is being developed and investigated.

The aim of the present study was to determine the storage life of retail meat cut while still hot and packaged in the simple way using dishes and 
shrinkable film, using vacuum packaging and controlled-atmosphere packaging.

$$
\text { Materials and Methods }
$$

Meat samples (pork chops and beef steaks from carcass halves) were taken from the slaughtered animals immediately after veterinary inspection at the slaughterhouse. The meat was prepared for cooking and sliced to approximately 100-150 g thick sheets which were weighed separately. Microbiological scrapings were taken and $\mathrm{pH}$, was measured in three places in all the samples. The samples were packed separately within two hours as follows:

(1) into PVC dishes covered with Al film on an automatic packing machine BTK. The dishes with the meat were flushed for $30 \mathrm{sec}$ with the following gas mixtures:

(a) $20 \% \mathrm{CO}_{2}$ and $80 \% \mathrm{O}_{2}$ (b) $20 \% \mathrm{CO}_{2}$ and $80 \% \mathrm{~N}_{2}$

The control analysis of the gas mixtures was done at the Research Institute LIKO Prague;

(2) vacuum packaging on a Swisvac packing machine into a Svitamid film;

(3) covering with a PE shrinkable film Chemosvit $0.030 \mathrm{~mm}$ on PVC dishes on a Holimatic M 40 line.

After packaging all the samples were placed in a refrigerator at a temperature ranging between 0 and $5 \% \mathrm{C}$. The samples were unpacked individually, one sample a day and the meat was examined organoleptically; after microbiological scraping the following was determined:

(1) weight of samples after storage

(2) remission (with an extension R 45/0 of the Specol Zeiss $549 \mathrm{~nm}$ colorimeter)

(3) $\mathrm{pH}$ (with a stabbing electrode Orion Res. 91-63)

(4) consistency (with a stabbing penetrometer OFD VEB Dresden AP 41)

(5) the water-binding capacity of the meat ( $K 1$ i m a 1979)

(6) ammonia content (Conway's method)

(7) dry matter $\left(105^{\circ} \mathrm{C}\right)$

(8) fat (extraction in a Soxhlet apparatus).

In the microbiological scrapings the following counts were determined:

(a) psychrotrophic MO(MPA $5^{\circ} \mathrm{C}, 5$ days)

(2) coliform MO (Endo, $37^{\circ} \mathrm{C}$, hours)

(3) anaerobic MO (VL agar, $37^{\circ} \mathrm{C}, 48$ hours in an anaerostat)

(4) mesophilic MO (MPA, $20^{\circ} \mathrm{C}, 48$ hours).

Organoleptic assessment was performed immediately after opening the package. The meat prepared for cooking was assessed using a linear graphical equation ( $\mathrm{P} \circ \mathrm{k} \circ \mathrm{r} \mathrm{n} \dot{\mathrm{y}}$ and $\mathrm{J}$ a $\mathrm{n} \dot{\mathrm{c}} \mathrm{e} k$ 1986) by a 5-member panel.

\section{$R$ e s u 1 t s}

The dynamics of organoleptic changes of packaged beef assessed immediately after opening the package is given in Tab. 1, of packaged pork in Tab. 2. Meat packaged in controlled atmospheres of 80 and $20 \% \mathrm{CO}_{2}$ had the best organoleptic quality, especially as concerns the bright red colour giving the impression of absolutely fresh meat. After culinary treatment, no statistically significant changes were found among the groups of packaged meat. Considerable 
Table 1

Dynamics of organoleptic changes of packaged beef

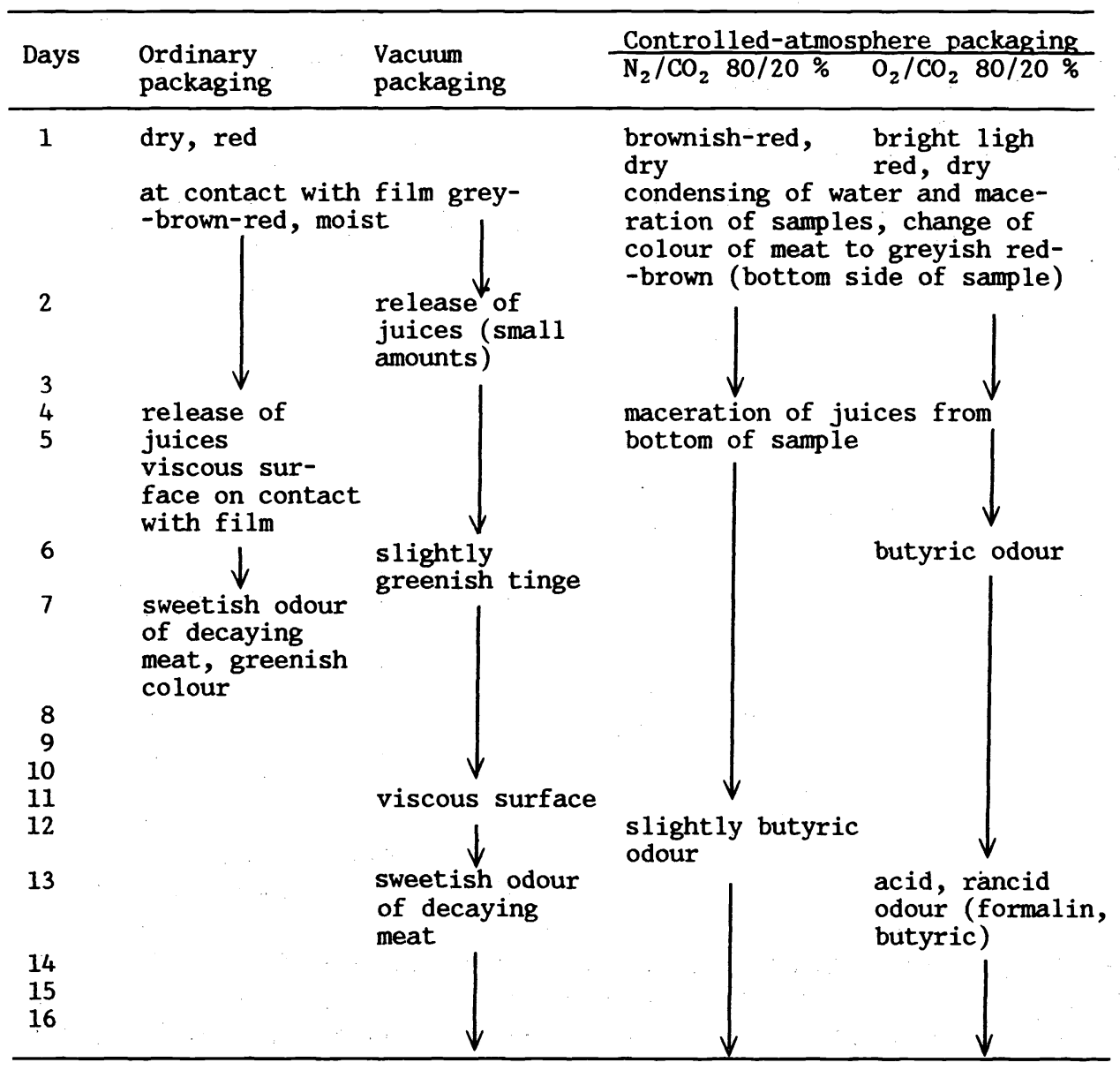

variations in the quality were observed among the individual samples and groups. Some organoleptic properties, namely the flavour, consistency and juiciness, spoiling the overall sensory assessment, were worse especially during the first five to six days in vacuum-packaged and controlled-atmosphere-packaged pork and during the first 3-4 days in meat packaged on dishes. In the majority of beef samples, the better organoleptic assessment shifted by 1-3 days, i.e. to the $7 \mathrm{th}-10 \mathrm{th}$ days of storage.

The $\mathrm{pH}$ values, namely $\mathrm{pH}$, and $\mathrm{pH}_{24}$, supported the suspicion that some meat samples had PSE and DFD defects (Tab. 3). These defects appeared as weight losses (5-12\%) 
Table 2

Dynamics of organoleptic changes of packaged pork

\begin{tabular}{|c|c|c|c|}
\hline Days & $\begin{array}{l}\text { Ordinary } \\
\text { packaging }\end{array}$ & $\begin{array}{l}\text { Vacuum } \\
\text { packaging }\end{array}$ & $\begin{array}{l}\text { Controlled-atmosphere packaging } \\
\mathrm{N}_{2} / \mathrm{CO}_{2} 80 / 20 \% \quad \mathrm{O}_{2} / \mathrm{CO}_{2} 80 / 20 \%\end{array}$ \\
\hline 1 & $\begin{array}{l}\text { greyish pink, } \\
\text { dry } \\
\text { at contact with } \\
\text { greyish }\end{array}$ & film pale, & $\begin{array}{l}\text { greyish pink, bright pink, } \\
\text { dry } \\
\text { maceration in condensed water, } \\
\text { bottom side of samples pale grey }\end{array}$ \\
\hline $\begin{array}{l}2 \\
3\end{array}$ & 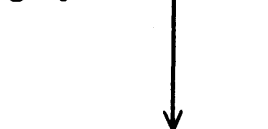 & $\begin{array}{l}\qquad \vee \\
\text { release of } \\
\text { juices (smal1 } \\
\text { amounts) }\end{array}$ & 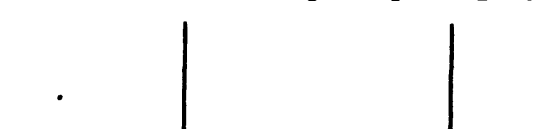 \\
\hline 4 & $\begin{array}{l}\text { release of } \\
\text { juices (sma11 } \\
\text { amounts) } \downarrow\end{array}$ & & \\
\hline $\begin{array}{l}5 \\
6 \\
7\end{array}$ & $\begin{array}{l}\text { viscous surface } \\
\text { odour of de- } \\
\text { caying meat }\end{array}$ & & 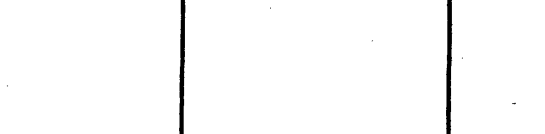 \\
\hline $\begin{array}{l}8 \\
9\end{array}$ & & & $\begin{array}{l}\text { slightly buty- } \\
\text { ric odour }\end{array}$ \\
\hline $\begin{array}{l}10 \\
11 \\
12 \\
13\end{array}$ & & $\begin{array}{l}\downarrow \\
\text { viscous surface }\end{array}$ & $\downarrow$ \\
\hline 14 & . & & $\begin{array}{l}\text { acid odour } \\
\text { (beginning) }\end{array}$ \\
\hline 15 & & $\begin{array}{l}\text { odour of de- } \\
\text { caying meat }\end{array}$ & $\downarrow$ \\
\hline 16 & & $\downarrow$ & $\begin{array}{l}\text { rancid, acid } \\
\text { odour (strong) }\end{array}$ \\
\hline
\end{tabular}

and/or in the binding capacity and remission (16-18\%). Using the F-test, no statistically significant differences in the $\mathrm{pH}$ values were observed among the different types of packagings.

Table 3

pH of packaged meat

\begin{tabular}{ccccccc}
\hline $\begin{array}{c}\text { Number } \\
\text { of } \\
\text { sample }\end{array}$ & $\mathrm{pH}_{1}$ & $\mathrm{pH}_{24}$ & $\begin{array}{c}\mathrm{pH} \\
\text { 16th day }\end{array}$ & $\mathrm{pH}_{1}$ & $\mathrm{pH}_{24}$ & $\begin{array}{c}\mathrm{pH} \\
\text { 16th day }\end{array}$ \\
\hline 1 & 6.5 & 6.1 & 6.2 & 6.5 & 5.7 & 5.7 \\
2 & 6.8 & 6.2 & 6.2 & 6.1 & 5.5 & 5.5 \\
3 & 6.7 & 6.5 & 6.3 & 6.2 & 5.6 & 5.6 \\
4 & 6.7 & 6.5 & 6.3 & 6.4 & 5.5 & 5.5 \\
5 & 6.8 & 5.6 & 5.5 & 6.6 & 5.6 & 5.6 \\
6 & 6.8 & 5.7 & 5.8 & 5.6 & 5.5 & 5.6 \\
\hline
\end{tabular}

In all the phase samples the $\mathrm{pH}$ values virtually stagnate during the whole period of storage.

The weight losses in beef and pork are given in 
Table 4

Storage life of hot-carcass-cut meat (in days)

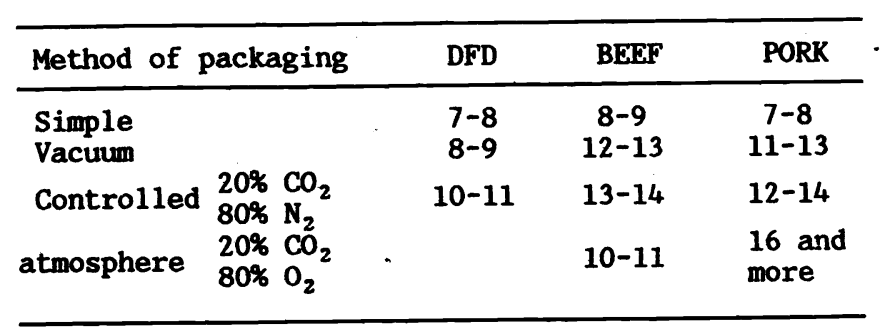

Fig. 1 and Fig. 2, respectively. Pork with a PSE defect was assessed separately since its high losses were completely baffling within all groups of packagings. The effect of the method of packaging

on weight losses in pork was proved statistically (with the exception of the PSE defect). No effects of different packagings were found in beef.

Using the F-test, statistically non-significant differences were found among the groups of packagings when measuring the ammonia content, tenderness, water-binding capacity and remission $(P>0.1)$.
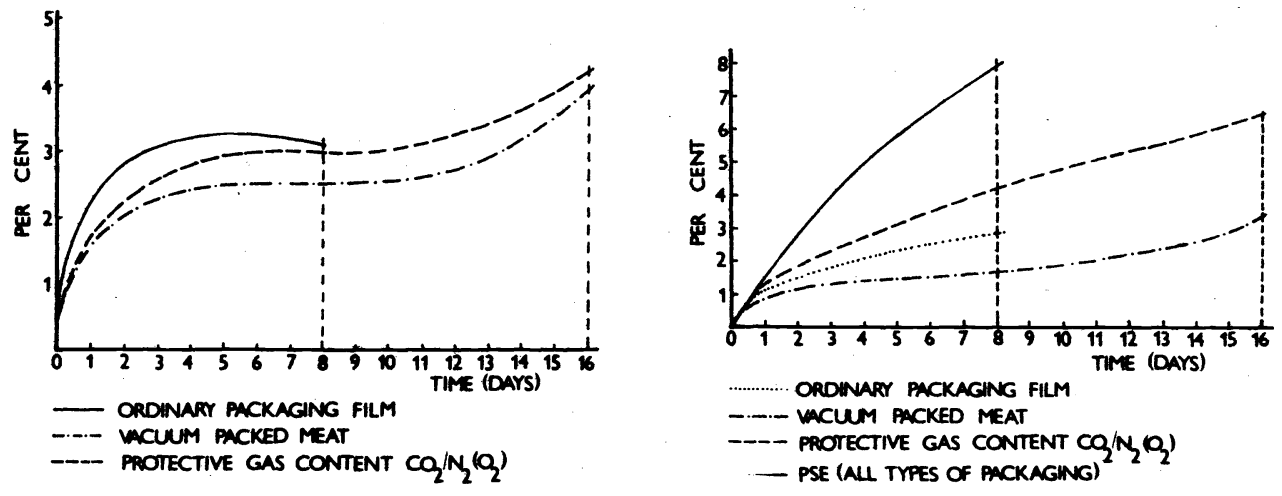

Fig. 1. Weight losses of retail Fig. 2. Weight losses of retail pork beef cuts cuts

In the individual samples of simple and vacuum packaging there was an evident correlation between the increased ammonia content and organoleptic variations and the microbiological findings. In meat packed in controlled atmosphere with $80 \% \mathrm{~N}_{2}$ and $20 \% \mathrm{CO}_{2}$, the increased values of ammonia were found only with advanced organoleptic changes. In meat packaged in coritrolled atmosphere and 


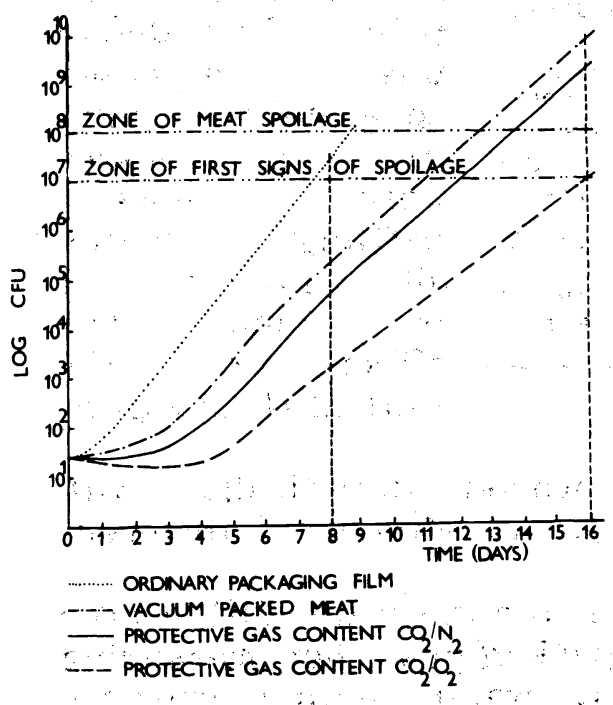

Fig. 3. Numbers of psychrotrophic bacteria on packaged retail beef cuts

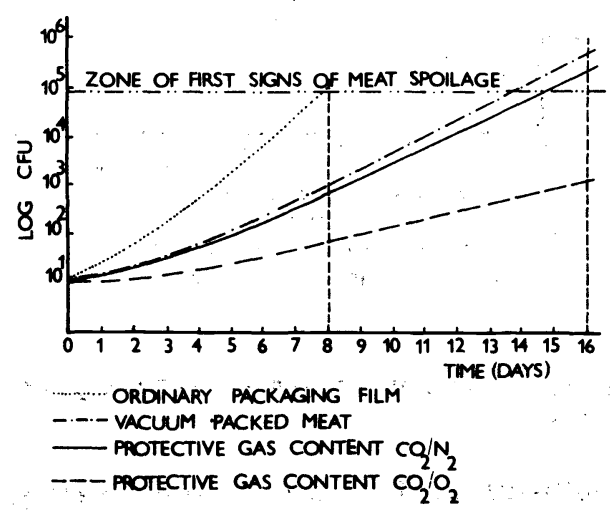

Fig. 5. Numbers of coliforms on packaged retail beef cuts

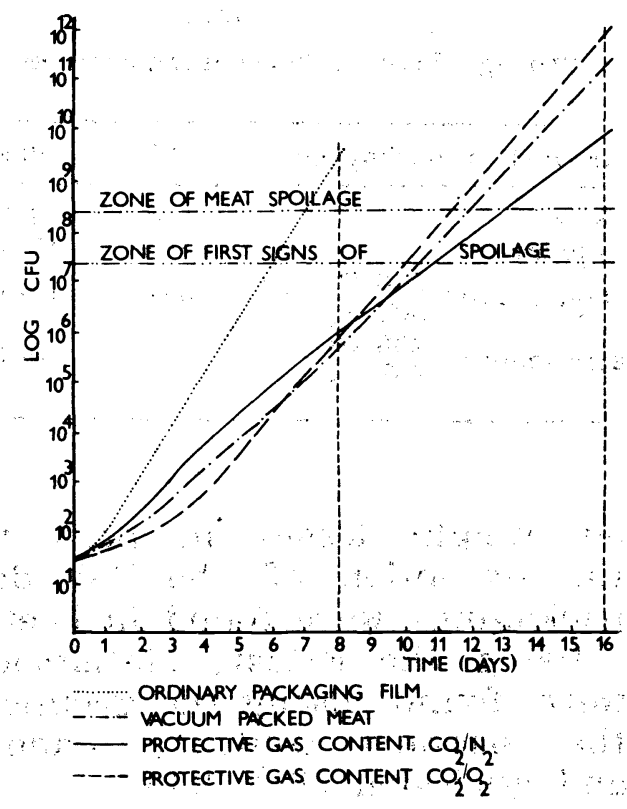

Fig. 4. Numbers of psychrotrophic bacteria on packaged retail pork cuts

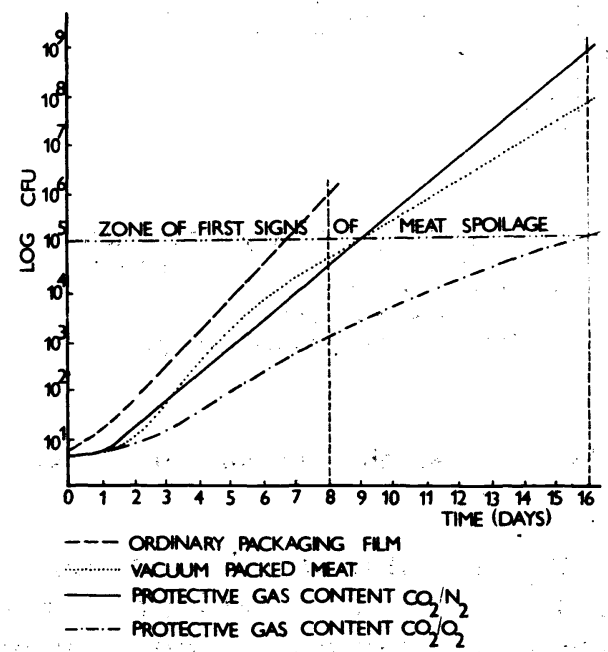

Fig. 6. Numbers of coliforms on packaged retail pork cuts 
organoleptically changed (butyric, acid and rancid odour), ammonia values were found to be within the standard of aged meat (ca $250 \mathrm{mg} / 100 \mathrm{~g}$ ).

The gradually increasing organoleptic changes in packaged meat were found to be correlated with counts of psychrotrophic microflora and coliform microflora.

The gradual growth in the count of psychrotrophic microflora in pork and beef is given in Fig. 3 and Fig. 4, respectively. The graphs show the initial meat contamination, the growth of microorganisms, the zones of the beginning organoleptic changes and the zone of spoilage. Similarly, Figs. 5 and 6 show the growths in the counts of coliform microorganisms in packaged samples during storage.

Comparisons of mesophile and anaerobic microflora showed that the differences among the groups of packagings were not statistically significant. In the samples the following genera of microorganisms were found: Pseudomonas, Alcaligenes, Flavobacterium, Enterobacter, Escherichia and Proteus. In meat in vacuum and controlled-atmosphere packagings, especially in the later stages of storage, a higher incidence of Lactobacillus, Pediococcus and Leuconostoc genera was found.

The organoleptic changes, microbiological picture and results of chemical analyses served as data for determinations of the maximal storage life of packaged meat as given in Tab. 4.

\section{D is c u s s i o n}

$\mathrm{K}$ a $\mathrm{s} t \mathrm{n}$ e $\mathrm{r}$ (1983) reports that boning the carcass while still hot has been introduced to meat-processing plants mainly because it reduces the costs required for refrigeration equipment and increases the turnover of meat in the plant (reduces losses, i.e. waste and dripping). In a comparative study, $E$ y $n$ r $d$ and $D u p i t$ (1985) proved that the productivity of labour is improved when applying hot carcass boning. The differences in the sensory properties, microbiological picture and stability of colour are not so univocal. Hot carcass boning is very demanding as concerns the hygienic requirements during the operation. $\quad B$ e $n$ e š (1986) described the lower dressing percentage and difficult retail cutting which is 
due to the easy separation of the individual muscles. The precondition for the successful introduction of hot carcass boning is immediate packaging. $\mathrm{B}$ e $11 \mathrm{a} \mathrm{m} \mathrm{y}$ et al. (1983) suggested vacuum packaging which is the most frequently used by meat producers in many countries in connection with hot carcass boning. A p p l e and $\mathrm{T}$ e $\mathrm{r} 1 \mathrm{i} \mathrm{z}$ i (1983) proposed that controlled-atmosphere packaging should be used to prolong the storage life of the meat.

The meat of the carcass cut while still hot is soft, springy, of a darker colour on the cut, with a clear mosaic of the muscle fibres frequently of different contraction. The stability of the colour of the meat depends mainly on the partial pressure of oxygen above the meat and the storage temperature. A $\mathbf{r} \mathbf{n}$ o 1 d (1984) reportd that the colour of meat stored in a controlled atmosphere with 60-80 $\%$ oxygen was oxihemoglobin bright red. When the oxygen is reduced to less than $60 \%$, what is called purple hemoglobin then appears. Under the effect of nitrogen (60-80 $\%$ ) the colour of the meat becomes greyish brown that is, however, reversible and after about 20-30 minutes changes to bright red ( $\mathrm{G}$ a $\mathrm{r}$ w o o d 1986). The increased content of oxygen in packaged meat favourably affects the colour, on the other hand however, it enables aerobic microflora to develop and reduces the storage life of the packaged meat.

The growth of aerobic psychrotrophic microflora is inhibited especially due to the increased $\mathrm{CO}_{2}$ content . F i s c h e r et al. (1983) investigated the effect of various proportions of constituents of the controlled atmosphere on the inhibition of microorganisms. The growth of microorganisms (namely Enterobacteriaceae) was proved to be significantly inhibited with as little as $20 \%$ of $\mathrm{CO}_{2}$ in the controlled atmosphere. It is true that with more than $40 \%$ of $\mathrm{CO}_{2}$ the growth is inhibited even more but also reversible browning of the meat occurs, similarly as in controlled atmospheres with a mixture of $\mathrm{N}_{2}$ and $\mathrm{CO}_{2}$. $\mathrm{H}$ a $\mathrm{m} m$ e $\mathrm{s}$ (1983) gives the best compromise between the stability of the meat colour and the antimicrobial effect of the protective-gas-controlled atmosphere on fresh meat, i.e. $20 \%$ of $\mathrm{CO}_{2}$ and $80 \%$ of $\mathrm{O}_{2}$. This proportion of gases is the most frequently used and recommended in practice.

$\mathrm{F}$ i s c $\mathrm{h}$ e $\mathrm{r}$ et al. (1983) drew attention to the possible different course of ageing of meat and especially to the onset of spoilage of meat packaged in controlled atmosphere 


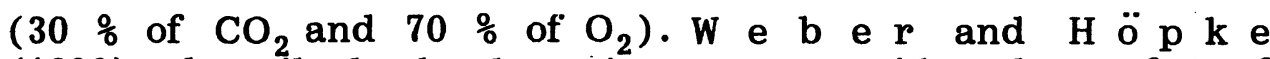
(1980) described the butyric, even rancid, odour of beef after long-term storage in an oxygen-controlled atmosphere. $F$ i s c $h$ e $r$ et al. (1983) did not find any correlation between these odours and the onset of oxidative changes in fats as was reported by $\mathrm{T}$ a y $10 \mathrm{r}$ (1973) in beef stored in a controlled atmosphere with an increased tension

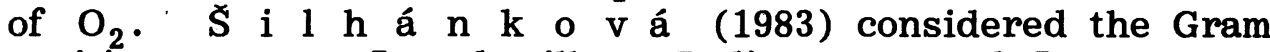
positive genera Lactobacillus, Pediococcus and Leuconostoc to be the causal organisms of homofermentative and heterofermentative lactic fermentation of vacuum-packed and protective-gas-atmosphere packaged meat; this phenomenon was also proved in our experiments. $\mathrm{N}$ e w $\mathrm{t}$ o $\mathrm{n}$ et al. (1977) considered Brochothrix thermosphacta and homofermentative lactobacilli to be the predominating microflora in meat packaged in a decreased tension of oxygen and increased amount of $\mathrm{CO}_{2}$ which stimulated their growth.

$\mathrm{N}$ e w t o $\mathrm{n}$ et al. (1977) reported that the predominating microflora of the early spoilage of meat packaged in the ordinary way (on dishes) in aerobic conditions was especially the genus Pseudomonas which appears in the typical slime formation and off-odour of decaying meat.

No authors described any marked differences in chemical analyses among the various methods of packaging. W e b e r and $\mathrm{H} \ddot{\mathrm{o}} \mathrm{p} \mathrm{k}$ e (1980) described the stagnation of the ammonia content during the storage of meat packed in an atmosphere with a content of protective gas and the slow, gradually very rapid, increase in the level of ammonia in meat packed on dishes. F i s c h e r et al. (1983) reported that the level of ammonia in meat packed in an atmosphere with a protective gas content (70 \% $\mathrm{O}_{2}$ and $30 \%$ of $\mathrm{CO}_{2}$ ) stagnated even when the sensory changes were so advanced that the meat became uneatable.

Vliv balení na vlastnosi hovězího a vepřového masa bouraného $\mathrm{v}$ teplém stavu

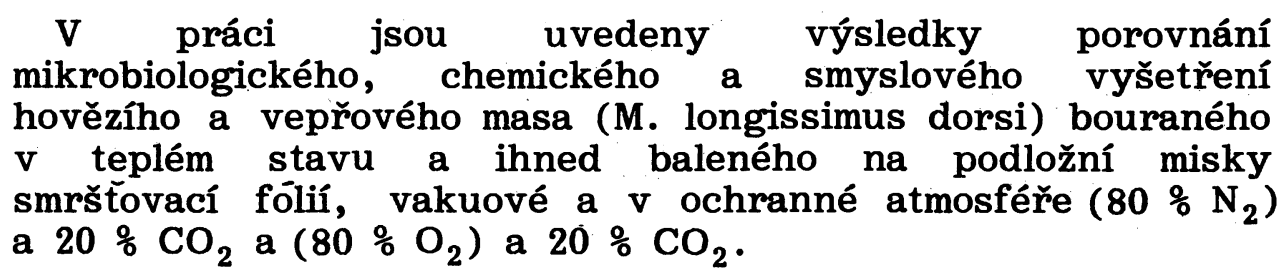


Balení masa vakuově a $v$ ochranné atmosfér̆e zvyšuje podstatně údržnost masa a snižuje intenzitu růstu přirozené mikroflóry masa. Smyslově nejlépe bylo hodnoceno maso $\mathrm{v}$ atmosféře $\mathrm{O}_{2} / \mathrm{CO}_{2}$, po tepelném opracování nebyly rozdíly prokázány. Smyslové odchylky masa $v$ zásadě korelují $\mathbf{s}$ mikrobiologickými nálezy, rozdíly byly zjištěny $\mathrm{v}$ porovnání s hodnotami amoniaku u masa baleného $v$ ochranné atmosféře. Hmotnostní ztráty baleného veprového masa jsou závislé především na biochemických vlastnostech masa, statisticky však byly prokázány i rozdíly mezi jednotlivými druhy balení po vyloučení PSE vad. U hovězího masa rozdíly prokázány nebyly, podobně jako $u$ ostatních sledovaných biochemických ukazatelů jakosti masa.

Влияние упаковки на свойства разделываемой в горячепарном состоянии говядины и свинины

В работе приведены резулътаты сопоставления микробиологических и химических а также резулътатов вкусовых и обонятелъных обследований разделываемой в горячепарном состоянии говядины и свинины (M. longissimus dorsj) и сразу же упаковываемой в вакуүме и защитной атмосФере $80 \% \mathrm{~N}_{2}$ и $20 \% \mathrm{CO}_{2}, 80 \% \mathrm{O}_{2}$ и $20 \%$ Ио на обернутых усадочной пленкой подносах.

Вакуумная упаковка мяса в защитной атмосфере существенно улучшает сохпанность мяса, понижая интенсивностъ роста его естественной микрофлоры. С точки зрения вкусовых и обонятелъных качеств самую высокую оценку получило мясо в атмосфере $\mathrm{O}_{2} / \mathrm{CO}_{2}$, после термообработки разница не была Установлена. Отклонения мяса по вкусу и обонянию находятся в принципе в корреляции С микробиологическими анализами, разница была установлена по сравнению с величинами аммиака Y мяса, упаковываемого в защитной атмосфере. Потери массы упакованной свинины зависят прежде всего от ее биохимических свойств, однако статистически была Үстановлена также разница между отделъными видами упаковки после исключения PSE дефектов. У говядины, как и $y$ осталъных исследуемых биохимических показателей качества мяса разница не была установлена. 
References

APPLE, J. M. - TERLIZZI, F. M.: Packaging systems for hot-boned beef. Food Techno1., 37, 1983: 68 - 77 .

ARNOLD, B.: Frischfleischverpackung Ablauf und Einrichtungsplanung. Fleischwirtschaft, $64,1984: 424$ - 427.

BELLAMY, M.: Quize jours de fraicheur. Alimentation, 1983: 51 - 53.

BENEŚ, J. - POLÁČKOVÁ, M. - NÁPRAVNÍKOVÁ, E. - HUJŇÁKOVÁ, M.: Výsledky srovnávacịch zkoušek př̀ baleni hověziho masa v teplém stavu a za 24 hodin po porážce. Zpravodaj MP CSR, 1986: 10 - 16.

EYNARD, P. - DUPIT, J.: Etude comparative des counts de transformation des viandes bovines entre les méthodes de travail classique, a chaud et a tiede. Viandes et produits carnes, 6, 1985: 199 - 203.

FISCHER, A. - HAMMES, W. P. - .BAUR, A. - SCHRAMM, A.: Lagerfähigkeit von Hackfleisch in kontrollierten Atmosphäre. 1. Einfluss auf physikalisch-chemische und sensorische Veränderungen. Fleischwirtschaft, 63, 1983: 1593 - 1602.

GARWOOD LIMITED: A Fresh approach to Packaging. Melbourne, 1986. 38 p.

HAMMES, W. P. In: FISCHER, A. - HAMMES, W. P. - BAUR, A. - SCHRAMM, A.: Lagerfähigkeit von Hackfleisch in kontrollierter Atmosphäre. 1. Einfluss auf physikalisch-chemische und sensorische Veränderungen. Fleischwirtschaft, 63, 1983: 1593 - 1602.

KASTNER, C. L.: Optimal hot-processing systems for beef. Food Techno1., 37, 1983: 96 - 100, 102, 107 .

KLIMA, D.: Návrh jednotlivých metod pro hodnoceni jakosti bilkovinných príisad do masných výrobkú. Zpravodaj masného prưmyslu ČSR, 1979: 70 - 73.

KRAMER, GREBE GmbH: Tiromat VA. Biedenkopf-Wallau, B.r., 8 p.

MULTIVAC EXPORT AG: Wo Multivac verpackt, funktioniert Bear, B.r., 6 p.

NEWTON, K. B. - RIGG, W. J.: The Effect of Film Permeability on the Storage life and Microbiology of Vacuum-packed meat. J. App1. Bacterio1. 47, 1979: 433 - 441.

POKORNÝ, J. - JANfCEK, G.: Senzorická analýza ve vztahu k chemii potravin. Chemické listy, 80, 1986: 1277.

ŠILHÁNKOVÁ, L.: Mikrobiologie pro potravináře. Ed. SNTL Praha, 304 p.

TAYLOR, A. A.: Gases in fresh meat packaging. Institute of Meat Bulletin, 79: $26-52$.

VOGNAROVÁ, I. - HUJŇ́KOVÁ. M.: Současná jakost hovězího masa. Průmys1 potravin, 37, 1986: 586 - 589 .

WEBER, H. - HOOPKE, H. U.: Der Einfluss einer kontrolierten Atmosphäre, bestehend aus $20 \% \mathrm{CO}_{2}$ und $80 \% \mathrm{O}_{2}$ auf die Haltbarkeit von portioniertem verpacktem Rindfleisch. Fleischwirtschaft, 60, 1980: 364 - 384. 